Ethiopian Journal of Environmental Studies \& Management 7(4): 460 - 467, 2014.

ISSN:1998-0507

doi: doi: http://dx.doi.org/10.4314/ejesm.v7i4.13

Submitted: May 24, 2014

Accepted: July 27, 2014

\title{
INFRASTRUCTURE FINANCING IN SELECTED LOCAL GOVERNMENT AREAS IN KOGI STATE-NIGERIA
}

\author{
*JIMOH, R.A. ${ }^{1}$ AND VAN WYK, J.J. ${ }^{2}$ \\ ${ }^{1}$ Building Department Federal University of Technoology Minna-Nigeria \\ ${ }^{2}$ Building/Human Settlements Department, Nelson Mandela Metropolitan University, Port
}

Elizabeth-South Africa

\begin{abstract}
The adequacy of infrastructure can affect the success of a country. In spite of the huge investment in infrastructure the world over, close to 3 billion people, or about $40 \%$ of the world's population will, by 2030, be in need of improved housing and basic infrastructure services (UN-Habitat, 2007). In this study, which set out to investigate the correlation between population density and budget allocations for infrastructural development, historical data on budget allocations for the period of 1997-2000 for infrastructural development in 15 Local Government Areas of Kogi State in Nigeria were examined, including the budgetary allocations made to rural electrification; water resources and water supply; roads and bridges; environmental sewage and drainage; town and country planning; and community development. Questionnaires were also administered to the Local Governments identified. Simple regression analysis was used to analyse the data. The results show that there was no statistically significant relationship between the variables measured and population density. Efforts should be made by the local governments of the areas to explore new ways and methods of boosting their internally generated revenues in order to bridge the gap between their revenues and responsibilities in relation to population density.
\end{abstract}

Key Words: Infrastructure development, local government, population density, budgetary allocation, financing

\section{Introduction}

Infrastructure is an umbrella term for many activities referred to as "social overhead capital", which include public utilities such as power, telecommunication, water supply, sanitation and sewerage; and public works such as roads, dams, and drainage (World Bank, 1994). Infrastructure includes all public services, ranging from law and order, through education and public health to transportation, communication, power and water supply as well as agricultural facilities such as irrigation and drainage systems. The adequacy of infrastructure helps to determine the level of success that a country achieves in terms of coping with population growth, reducing poverty, or improving environmental conditions (World Bank, 1994). In a report on a related development, Khan and Haupt (2006) stated that one of the benchmarks used in determining the well-being of the populace is to have the minimal infrastructural services. Evidence suggests that inadequate infrastructure is an impediment to the rate of growth in Africa,

*Corresponding Author: Jimoh, R.A.

Email: rosney@futminna.edu.ng 
which has resulted in some African countries trailing behind other developing countries (Foster and Briceno-Garmendia, 2010).

Developing countries, according to the World Bank (1994), invested \$200 billion per year in new infrastructure. This has resulted in a dramatic increase in infrastructure services leading to higher productivity and improved standard of living. But in spite of this positive information, close to 3 billion people, or about $40 \%$ of the world's population will be in need of adequate housing and basic infrastructure services by 2030 (UN-Habitat, 2007). According to the United Nations (2010) 884 million people lack access to potable water and 2.6 billion people lack access to basic sanitation services. To bridge this infrastructural deficiency gap in sub-Saharan Africa, Foster and Briceno-Garmendia (2010) indicated that $\$ 93$ billion is needed yearly. Infrastructure and the provision of housing are, according to Otegbulu and Adewunmi (2009) closely related; to have housing that is sustainable, there is a need for the provision of infrastructure.

For developing countries, investments in infrastructure have benefits as well as costs associated with the benefits. In areas where transportation, communication, and power generation are inadequate, increased supplies can do much to boost productivity and growth. Furthermore, where income and productivity are depressed by inadequate infrastructure, the financial resources needed may be huge and the challenges of obtaining finance may be serious and difficult to overcome. Due to the fact that the lack of infrastructure limits investment and the lack of investment limits infrastructure, this may not be unconnected with the level of investments seen in developing countries (Eichengreen, 1995).

Providing appropriate infrastructure in developing countries can play a vital role in poverty reduction. The development of social infrastructure is important in contemporary societies where education and healthcare are strategic factors for economic growth, social progress and the competitiveness of the country in global markets (Chulanova, 2007). In countries where the development of this infrastructure has followed a rational, coordinated and harmonized path, growth has received a big boost. This is because infrastructure provision and development serve as input into private sector production, thus facilitating output growth and productivity.

In allocating revenue to the component units of the central government such as the local or state government, there are various factors that are usually considered depending on the goal of the central government at that point in time. Boex and Martinez-Vazquez (2005) classify the factors as follows, expenditure needs (population density, dependent population, urbanisation, poverty and human development index); fiscal capacity; political power and population size.

Studies have shown that the factors that correlate with revenue allocations are not the same in all countries. In Uganda for example, the Local Government Finance Commission of Uganda (2003) established that population density has a correlation with revenue allocation at the local government level. In Nigeria, Alm and Boex (2002) discovered that revenue allocation to state governments had no statistical relationship with population density; hence no correlation between them. In a related development, in Tanzania, Boex (2003) stated that population density, poverty and population size do not have any statistical relationship with revenue allocation at the local government level.

In spite of the findings from the aforementioned studies, logical reasoning leads that budgetary allocation should consider and correlate positively with population density; 
the more dense a population is in a given area, the higher the demand will be on infrastructure services. Therefore the budgetary allocations should also correlate positively with population density.

Achunine (1993) established that the common practice in Nigeria is for the public sector to be directly involved in the financing, provision and operation of infrastructural services. The Government makes (lump sum) annual budgetary allocations for infrastructure, but then it is left to its officials (through direct labour or with contractors) to build or install the roads, water supply and drainage systems, sewerage networks, electricity and communication facilities in new residential layouts. As a result of inadequate funding, coupled with budget fluctuations, the high cost of these services and the influence of spiralling prices, it sometimes takes up to 10 years to provide these services to a property after it is made available for development. Achunine (ibid) further states the responsibility for the provision of infrastructure and services is often beyond the financial capability of the public sector, especially at the Local Government level.

Prior to the inclusion of the Local Government in the sharing of the Federation Account in 1979, the inadequacy of finance was the most frequently mentioned constraint to the effective participation of Local Government in national development in Nigeria. Abubakar (1993) identified two main sources of revenue for Local Governments in Nigeria; namely the internal (community rates and taxes, cattle tax, property taxes or tenement rates, and land rents) and external sources (the Federation Account, statutory contributions of State Governments).

Abubakar (ibid) concludes that Nigerian Local Governments characteristically spend the bulk of their revenues on servicing recurrent expenditures. The resultant effect is that little is left for the provision of new infrastructure. It is with this in view that the paper sought to provide answers to the following research questions:

What are the various sources of finance available to the Local Government Areas?

Is there any statistical relationship between the budgetary allocations to infrastructure (rural electrification; roads and bridges; water resources and supply; environmental sewage and drainage; town and country planning; community development) and population density?

\section{Research Methodology}

The adopted methodology followed the mixed methods approach. As a result of the insufficiency of the first set of data collected, the embedded design method, as described by Creswell and Clark (2011), was used. The design is such that one set of data is used to provide support for the other set and as such the supportive data is said to be embedded in the main data. The second set of data (the survey) provided the support for the historical data.

Historical data from 1997-2000 was extracted from the records of the Department of Local Government and Chieftaincy Affairs, Deputy Governor's Office. Budgetary allocations to the following infrastructural services were obtained and analysed: Rural electrification; water resources and water supply; roads and bridges; environmental sewage and drainage; town and country planning; and community development. Fifteen (15) Local Government Areas were studied out of the 21 Local Government Areas in Kogi State. All the Areas in this sample size had complete information regarding the years under review and they were representative of the 3 senatorial districts in the State. Population figures and demarcation of these 
geographical areas were based on the 1991 population census. Simple regression analysis was done using the Statistical Package for Social Scientists (SPSS) for data analysis. In addition, questionnaires were selfadministered to determine the variables such as sources of finance and loans sought from the Infrastructure Development Fund (IDF) in the 15 Local Government Areas studied. Finally, inferences were drawn that formed the basis for the conclusion and recommendations.

\section{Data Analysis}

Table 1: Simple Regression Analysis on Budgetary Allocation for Rural electrification and Population Density

\begin{tabular}{llccccc}
\hline YEAR & REGRESSION EQUATION & $\mathrm{R}^{2}$ & FCAL & FTAB & P & REMARK \\
\hline 1997 & 965466 - 679 Pdensity & $2.9 \%$ & 0.39 & 4.67 & 0.543 & NS \\
1998 & $1705994-1013$ Pdensity & $3.0 \%$ & 0.40 & 4.67 & 0.540 & NS \\
1999 & 1988849 - 1204 Pdensity & $5.0 \%$ & 0.69 & 4.67 & 0.422 & NS \\
2000 & 3863041 - 3463 Pdensity & $4.0 \%$ & 0.54 & 4.67 & 0.476 & NS \\
\hline
\end{tabular}

Since the F-calculated value of 0.69 (the highest of all the F-calculated values) is less than Ftabulated of 4.67 , the relationship is statistically not significant for all the years at $95 \%$ confidence level. In addition to this, all the years recorded very low coefficient of determination $\left(\mathrm{R}^{2}\right)$, the highest $\mathrm{R}^{2}$ value of $5.0 \%$ shows that only this percentage of variations in budgetary allocation for rural electrification are explained for by the population density.

Table 2: Simple Regression Analysis on Budgetary Allocation for Roads and Bridges and Population Density.

\begin{tabular}{llccccc}
\hline YEAR & REGRESSION EQUATION & $\mathrm{R}^{2}$ & FCAL & FTAB & \multicolumn{1}{c}{$\mathrm{P}$} & REMARK \\
\hline 1997 & 2588324 - 898 Pdensity & $0.9 \%$ & 0.11 & 4.67 & 0.742 & NS \\
1998 & 3191469 + 1365 Pdensity & $1.2 \%$ & 0.16 & 4.67 & 0.697 & NS \\
1999 & 3906624 + 1581 Pdensity & $2.6 \%$ & 0.34 & 4.67 & 0.569 & NS \\
2000 & 6294904 + 9724 Pdensity & $16.3 \%$ & 2.53 & 4.67 & 0.136 & NS \\
\hline
\end{tabular}

Since the F-calculated value of 2.53 (the highest of all the F-calculated values) is less than Ftabulated of 4.67 , the relationship is statistically not significant for all the years. The highest $\mathrm{R}^{2}$ value of $16.3 \%$ shows that only this percentage of variations in budgetary allocation for roads and bridges are accounted for by the population density.

Table 3: Simple Regression Analysis on Budgetary Allocation for Water Resources and Supply and Population Density

\begin{tabular}{llccccc}
\hline YEAR & REGRESSION EQUATION & $\mathrm{R}^{2}$ & FCAL & FTAB & P & REMARK \\
\hline 1997 & $1274869-907$ Pdensity & $5.0 \%$ & 0.69 & 4.67 & 0.421 & NS \\
1998 & $1384410+$ 270 Pdensity & $0.6 \%$ & 0.07 & 4.67 & 0.790 & NS \\
1999 & $1631459+289$ Pdensity & $0.6 \%$ & 0.07 & 4.67 & 0.792 & NS \\
2000 & 2719503 - 566 Pdensity & $0.9 \%$ & 0.11 & 4.67 & 0.741 & NS \\
\hline
\end{tabular}

Since the F-calculated value of 0.69 (the highest of all the F-calculated values) is less than Ftabulated of 4.67 , the relationship is statistically not significant for all the years. The highest $\mathrm{R}^{2}$ 
value of 5.0\% shows that only this percentage of variations in budgetary allocation for water resources and supply are explained for by the population density.

Table 4: Simple Regression Analysis on Budgetary Allocation for Environmental Sewage and Drainage and Population Density

\begin{tabular}{llccccc}
\hline YEAR & REGRESSION EQUATION & $\mathrm{R}^{2}$ & FCAL & FTAB & $\mathrm{P}$ & REMARK \\
\hline 1997 & $378510+1255$ Pdensity & $17.0 \%$ & 2.66 & 4.67 & 0.127 & NS \\
1998 & $607261+1202$ Pdensity & $18.9 \%$ & 3.03 & 4.67 & 0.105 & NS \\
1999 & $901418+1738$ Pdensity & $13.5 \%$ & 2.03 & 4.67 & 0.178 & NS \\
2000 & $1341200+4104$ Pdensity & $33.2 \%$ & 6.45 & 4.67 & 0.025 & SN \\
\hline
\end{tabular}

Since the F-calculated value of 3.03 between 1997 and 1999 is less than F-tabulated of 4.67, the relationship is statistically not significant. While for year 2000, F-calculated value of 6.45 is greater than F-tabulated of 4.67, hence the relationship is statistically significant. The highest $R^{2}$ value of $33.2 \%$ shows that only this percentage of variations in budgetary allocation for environmental sewage and drainage are explained for by the population density.

Table 5: Simple Regression Analysis on Budgetary Allocation for Town and Country Planning and Population Density

\begin{tabular}{llccccc}
\hline YEAR & REGRESSION EQUATION & $\mathrm{R}^{2}$ & FCAL & FTAB & P & REMARK \\
\hline 1997 & $276644+286$ Pdensity & $1.8 \%$ & 0.24 & 4.67 & 0.633 & NS \\
1998 & $305025+705$ Pdensity & $20.5 \%$ & 3.36 & 4.67 & 0.090 & NS \\
1999 & $305496+893$ Pdensity & $12.0 \%$ & 1.76 & 4.67 & 0.207 & NS \\
2000 & $1160738+856$ Pdensity & $2.1 \%$ & 0.27 & 4.67 & 0.610 & NS \\
\hline
\end{tabular}

Since the F-calculated value of 3.36 (the highest of all the F-calculated values) is less than Ftabulated of 4.67, the relationship is statistically not significant for all the years. The highest $\mathrm{R}^{2}$ value of $20.5 \%$ shows that only this percentage of variations in budgetary allocation for town and country planning are explained for by the population density.

Table 6: Simple Regression Analysis on Budgetary Allocation for Community Development and Population Density

\begin{tabular}{llccccc}
\hline YEAR & REGRESSION EQUATION & $\mathrm{R}^{2}$ & FCAL & FTAB & $\mathrm{P}$ & REMARK \\
\hline 1997 & $462947-369$ Pdensity & $3.9 \%$ & 0.53 & 4.67 & 0.478 & NS \\
1998 & $581654-147$ Pdensity & $0.3 \%$ & 0.04 & 4.67 & 0.848 & NS \\
1999 & 815976 + 27 Pdensity & $0.4 \%$ & 0.06 & 4.67 & 0.816 & NS \\
2000 & 934297 - 203 Pdensity & $0.4 \%$ & 0.05 & 4.67 & 0.828 & NS \\
\hline
\end{tabular}

Since the F-calculated value of 0.53 (the highest of all the F-calculated values) is less than Ftabulated of 4.67, the relationship is statistically not significant for all the years. The highest $\mathrm{R}^{2}$ value of $3.9 \%$ shows that only this percentage of variations in budgetary allocation for community development are accounted for by the population density. 
Table 7: Representation of the Local Government Areas, the sources of funds available and IDF loans

\begin{tabular}{|c|c|c|c|c|c|c|c|c|c|}
\hline \multirow{2}{*}{ LG } & \multicolumn{5}{|c|}{ Sources of funds } & \multicolumn{4}{|c|}{ Loans from IDF } \\
\hline & FA & SG & IDF & IGR & VAT & 1997 & 1998 & 1999 & 2000 \\
\hline Adavi & $\mathrm{Y}$ & $\mathrm{N}$ & $\mathrm{N}$ & $\mathrm{Y}$ & $\mathrm{Y}$ & $\mathrm{N}$ & $\mathrm{N}$ & $\mathrm{N}$ & $\mathrm{N}$ \\
\hline Ajaokuta & Y & $\mathrm{N}$ & $\mathrm{N}$ & Y & Y & $\mathrm{N}$ & $\mathrm{N}$ & $\mathrm{N}$ & $\mathrm{N}$ \\
\hline Ankpa & Y & $\mathrm{N}$ & $\mathrm{N}$ & Y & Y & $\mathrm{N}$ & $\mathrm{N}$ & $\mathrm{N}$ & $\mathrm{N}$ \\
\hline Bassa & $\mathrm{Y}$ & $\mathrm{N}$ & $\mathrm{N}$ & Y & Y & $\mathrm{N}$ & $\mathrm{N}$ & $\mathrm{N}$ & $\mathrm{N}$ \\
\hline Dekina & $\mathrm{Y}$ & $\mathrm{N}$ & $\mathrm{N}$ & Y & Y & $\mathrm{N}$ & $\mathrm{N}$ & $\mathrm{N}$ & $\mathrm{N}$ \\
\hline Ibaji & \multicolumn{9}{|c|}{ Area not accessible due to rainfall at that time of the year } \\
\hline Ijumu & Y & $\mathrm{N}$ & $\mathrm{N}$ & Y & $\mathrm{Y}$ & $\mathrm{N}$ & $\mathrm{N}$ & $\mathrm{N}$ & $\mathrm{N}$ \\
\hline Kabba/Bunu & $\mathrm{Y}$ & $\mathrm{N}$ & $\mathrm{N}$ & Y & $\mathrm{Y}$ & $\mathrm{N}$ & $\mathrm{N}$ & $\mathrm{N}$ & $\mathrm{N}$ \\
\hline Kogi & $\mathrm{Y}$ & $\mathrm{N}$ & $\mathrm{N}$ & Y & Y & $\mathrm{N}$ & $\mathrm{N}$ & $\mathrm{N}$ & $\mathrm{N}$ \\
\hline Mopamuro & Y & $\mathrm{N}$ & $\mathrm{N}$ & $\mathrm{Y}$ & Y & $\mathrm{N}$ & $\mathrm{N}$ & $\mathrm{N}$ & $\mathrm{N}$ \\
\hline Ogori & $\mathrm{Y}$ & $\mathrm{N}$ & $\mathrm{N}$ & Y & Y & $\mathrm{N}$ & $\mathrm{N}$ & $\mathrm{N}$ & $\mathrm{N}$ \\
\hline Okehi & Y & $\mathrm{N}$ & $\mathrm{N}$ & Y & Y & $\mathrm{N}$ & $\mathrm{N}$ & $\mathrm{N}$ & $\mathrm{N}$ \\
\hline Okene & $\mathrm{Y}$ & $\mathrm{N}$ & $\mathrm{N}$ & Y & Y & $\mathrm{N}$ & $\mathrm{N}$ & $\mathrm{N}$ & $\mathrm{N}$ \\
\hline Olamaboro & Y & $\mathrm{N}$ & $\mathrm{N}$ & Y & Y & $\mathrm{N}$ & $\mathrm{N}$ & $\mathrm{N}$ & $\mathrm{N}$ \\
\hline Omala & Y & $\mathrm{N}$ & $\mathrm{N}$ & Y & Y & $\mathrm{N}$ & $\mathrm{N}$ & $\mathrm{N}$ & $\mathrm{N}$ \\
\hline
\end{tabular}

LG-Local Government; FG-Federation Account; SG-State Government; IDF-Infrastructure Development Fund; IGR-Internally Generated Revenue; VAT-Value Added Tax; Y-Yes and N-No.

From Table 7 above, the sources of funds available to the Local Government Areas were from the Federation Account, internally generated revenue and Value Added Tax (VAT). It was discovered that none of the 14 Local Government Areas benefitted from the loans from the IDF, as no funds were provided from this source (the IDF).

The results from Tables 1-3 and 5-6 are consistent with the studies of Alm and Boex (2002) and Boex (2003) while the result in Table 4 is consistent with the study of Edame and Ejue (2013) that there is a significant relationship between budgeting and infrastructural development in Nigeria. The result of the study from Edame and Ejue (2013) is not surprising because the study area is in the Niger Delta region where the monthly allocation accruing to the State from the Federation Account is higher than what accrues to Kogi State. Table 7 result is consistent with Abubakar (1993) study with regards to the sources of funds available in Nigeria. That Local Governments in the areas studied had not benefitted from IDF loans may be one of the reasons why Alm and Boex (2002) concluded that Local Governments have only limited opportunities to borrow in Nigeria, because banks, financial institutions and individuals are unwilling to lend money to Local Governments. Due to this limited sources of funds, the provision of infrastructure at the various Local Government Areas is stymied.

There is a fiscal mismatch between revenues and responsibilities coupled with the fact that the bulk of the revenues are spent on recurrent expenditures, as stated by Abubakar (1993). This is reflected in the findings of this study, which indicate that budget allocations for infrastructure do not correlate with the population density of the areas concerned.

\section{Conclusion and Recommendations}

From the findings, non-provision of infrastructure development fund (IDF) loans and statutory allocation of funds from the State Government to the Councils might have contributed to the inadequate funds provided 
for infrastructural facilities. This would have augmented the allocations from the Federation Account and VAT. The budgetary allocations had no statistically significant relationship with parameters such as population density.

The following recommendations are hereby made;

- The State Government should, as a matter of its responsibility, not only provide statutory allocations to all the Local Government Areas as enshrined in Section 7, Subsection 6b of the 1999 Constitution, but also ensure that its supervisory department (Department of Local Government) perform its function effectively in the area of strict budget compliance by councils. A means should be found by the Federal Government, perhaps through appropriate legislation of compelling the State Government, to contribute its expected share of revenue into the coffers of Local Governments as and when due.

- Budget should be such that qualified personnel are involved in its preparation so that parameters such as population figures, geographical area and population density are considered. Professionals in the relevant disciplines such as construction management, town planning and quantity surveying should be employed and they should be well remunerated so that perennial enticement and absorption of their staff by the Federal and State Governments, which had and still have more attractive conditions of service, will stop.

- Local Government Councils should explore new ways and methods of boosting their internally generated revenue, the rendering of consultancy services (for example construction management services to developers and contractors), in order to bridge the gap between their revenues and responsibilities.

- The Federal Government should serve as guarantor in order for the Local Government Areas to have access to loans for financing infrastructural development initiatives.

- The areas that Local Governments can statutorily legislate upon should be expanded especially in relation to taxation, so that their internally generated revenue can be enhanced.

\section{References}

Abubakar, H. I. (1993). Autonomy and Financial Administration in Nigeria Local Governments. The Nigerian Journal of Public Affairs, XIII(1)

Achunine, B.O. (1993). National Trends in Housing Production Practices in Nigeria- Case study prepared for UNCHS (Habitat)

Alm, J. and Boex, J. (2002). An overview of intergovernmental fiscal relations and sub-national public finance in Nigeria. International studies programme working paper number 02-1, Andrew Young School of Policy Studies, Georgia State University

Boex, J. (2003). The incidence of local government allocations in Tanzania. International studies programme working paper number 03-11, Andrew Young School of Policy Studies, Georgia State University.

Boex, J. and Martinez-Vazquez, J. (2005). The determinants of the incidence of intergovernmental grants: A survey of the international experience. International studies programme working paper number 06-52, Andrew Young School of Policy Studies, Georgia State University 
Infrastructure Financing in Selected Local Government Areas................JIMOH \& van WYK

Chulanova, Z. (2007) Poverty Reduction in Developing Countries via Infrastructure Development \& Economic Growth: Mutual Impact in Kazakhstan. Asian Development Bank Institute Discussion Paper no. 62

Creswell, J.W. and Clark, V.L.P. (2011). Designing \& conducting mixed methods research, $2^{\text {nd }}$ edition. California: Sage Publications, Inc.

Edame, G.E. and Ejue, M.O. (2009). Budgeting role, infrastructural development and economic growth in Nigeria. European Journal of Business and Social Sciences, 2(6), 115

Eichengreen, B. (1995). Financing Infrastructure in Developing Countries: Lessons from the Railway Age. The World Bank Research Observer, 10(1)

Foster, V. and Briceno-Garmendia, C. (Editors) (2010). Africa's infrastructure: $A$ time for transformation. Washington: The World Bank

Khan, Z and Haupt, T.C. (2006). Community participation - a necessary element of community development projects. ACTA Structilia, 13(2)

Otegbulu, A. and Adewunmi, Y. (2009). Evaluating the sustainability of urban housing development in Nigeria through innovative infrastructure management. International Journal of Housing Markets and Analysis, 2(4)

Ugandan Local Government Finance Commission (2003). Fiscal decentralisation strategy, phase II: allocation principles and development of allocation formulae.

UN-Habitat (2007). Business for sustainable urbanisation: Challenges and opportunities. Available from: www.UN-Habitat.org/.../2344_alt[1].pdf (Accessed 26 January 2010)

United Nations (2010). We can end poverty by 2015: Millennium Development Goals Fact Sheet. High-level plenary meeting of the General Assembly, 2022 September. Available from: www.un.org/millennium/.../MDG_FS_7_ EN.pdf (Accessed 22 March 2011)

World Bank (1994). Infrastructure for Development: World Development Report, Executive Summary, Washington, D.C. 